\title{
The effects of additional organic copper and organic zinc trace minerals on accumulation and elimination levels in female kids
}

\author{
Vadullah EREN ${ }^{1}$, Özdal GÖKDAL ${ }^{1}$, Hasan AKŞiT'² ${ }^{2}$ Okan ATAY $^{1}$, Ali Kemali ÖZUĞUR ${ }^{1}$ \\ ${ }^{1}$ Adnan Menderes University, Çine Vocational School, 09500, Çine-Aydın; ${ }^{2}$ Balıkesir University, Veterinary Faculty, Department of \\ Biochemistry, Balıkesir, Turkey.
}

Summary: This study was conducted to evaluate the accumulation of copper and zinc in serum, hair and feaces of goats fed diets supplemented with organic $\mathrm{Cu}$ and $\mathrm{Zn}$ at levels of $25 \%$ lower than NRC (12) recommendations. Totally female kids were divided equally into two groups fed rations supplemented with organic (treatment, $n=12$ ) and inorganic (control, $n=12)$ copper and zinc. Treatment diets was supplemented with $5.25 \mathrm{mg} / \mathrm{kg}$ DM copper chelate (2-hydroxy-4-methylthiobutyrate) and $15 \mathrm{mg} / \mathrm{kg} \mathrm{DM}$ zinc chelate (2-hydroxy-4-methylthiobutyrate) whereas control diet was supplemented $7 \mathrm{mg} / \mathrm{kg}$ DM copper sulphate, $20 \mathrm{mg} / \mathrm{kg}$ DM zinc sulphate in the ration. At the end of the experiment in both treatments copper and zinc levels in serum and copper and zinc levels in hair samples were found higher than the average values at the beginning of the experiment, but the difference between the average values were not statistically significant. The average copper and zinc levels in serum and copper levels in hair samples of treatment group were found numerically higher than control group. Moreover the average zinc levels in hair samples were also numerically higher in control group. At the end of the study, the average faeces copper and zinc levels $(\mathrm{P}<0.001)$ were significantly lower in the treatment group. Although organic copper and zinc were given to the female kids in low levels (at level of $25 \%$ ), we confirmed that this amount gave similar results to inorganic copper and zinc and organic minerals were found at lower levels in the faeces.

Key words: Copper, faeces, hair, organic mineral, serum, zinc

\section{Rasyona eklenen organik bakır ve organik çinko iz minerallerinin dişi oğlaklarda birikim ve atılma düzeyleri üzerine etkisi}

Özet: Bu çalışma, NRC (12) tarafından keçiler için önerilen düzeylerin \%25'i oranında azaltılarak rasyona eklenen organik yapıdaki bakır $(\mathrm{Cu})$ ve çinko $(\mathrm{Zn})$ minerallerinin serum ve kıldaki mineral birikim düzeyi ile dışkıda atılan mineral düzeyine etkisini değerlendirmek için yapıldı. Oğlaklar biri organik (deneme, $n=12$ ) ve diğeri inorganik (kontrol, $n=12$ ) bakır ve çinko minerallerini içeren rasyon verilen iki gruba ayrıldı. Deneme grubuna $5.25 \mathrm{mg} / \mathrm{kg} \mathrm{KM}$ bakır-şelat (2-hydroxy-4-methylthiobutyrate) ve $15 \mathrm{mg} / \mathrm{kg}$ KM çinko-şelat (2-hydroxy-4-methylthiobutyrate), kontrol grubuna ise $7 \mathrm{mg} / \mathrm{kg} \mathrm{KM}$ bakır-sülfat, $20 \mathrm{mg} / \mathrm{kg} \mathrm{KM}$ çinko-sülfat verildi. Deneme sonunda her iki grubun serum bakır ve serum çinko ile kıl bakır ve kıl çinko ortalama değerlerinin deneme başına göre daha yüksek düzeyde olduğu, ancak ortalama değerler arasındaki farkın istatistiksel açıdan önemli olmadığı belirlendi. Serum bakır ve serum çinko ile k1l bakır ortalama değerlerinin deneme grubunda, k1l çinko ortalama değerinin ise kontrol grubunda rakamsal olarak daha yüksek düzeyde olduğu saptand1. Dışkı bakır ve dışkı çinko ortalama düzeylerinin deneme grubunda kontrol grubuna göre önemli oranda $(\mathrm{P}<0.001)$ düşük olduğu belirlendi. Organik bakır ve organik çinkonun oğlak rasyonunda \%25 oranında daha düşük düzeyde kullanılmalarına rağmen inorganik bakır ve inorganik çinko ile benzer ve dışkıda daha düşük bir sonuç ortaya koydukları saptanmıştır.

Anahtar sözcükler: Bakır, çinko, dışk1, k1l, organik mineral, serum

\section{Introduction}

Low concentrations of trace minerals in the organism, even after making much important physiological mechanism is required for continuity. Otherwise lose the health of animals, the yield falls, and serious economic losses occur $(22,26)$. It is well known that trace mineral deficiency and diseases affiliated with mineral deficiencies are prevalent in worldwide. Inorganic salts (oxides, sulfates) are generally added to the diet to prevent deficiencies $(20,22,26)$. However, trace minerals usually antagonize other elements within the diet. They are generally added to the diet in low levels. High-level utilization poses a risk of toxicity and causes pollution by increasing discharge in the faeces $(11,20)$.

Because organic minerals are absorbed without alterations, except for large molecule proteinates, and are stored in their same organic forms because no antagonism is formed, it has been stated that absorption and bioavailability of organic minerals are high $(3,16,23)$. It is also known that organic minerals are not discharged by feaces as much as inorganic minerals because they are found in smaller levels in the diet $(2,15,17,27)$. 
In this study, it was aimed to compare the levels of $\mathrm{Cu}$ and $\mathrm{Zn}$ levels in serum, hair and faeces of kids fed diets supplemented with organic mineral sources and kids fed diets $25 \%$ lower than recommended mineral levels.

\section{Material and Method}

A total of twenty four, 9 months old female Saanen $\mathrm{x}$ Hair Goat $\left(\mathrm{F}_{1}\right)$ and Alpin $\mathrm{x}$ Hair Goat $\left(\mathrm{F}_{1}\right)$ kids were used in the study. The female kids were divided into two groups as following: control $\left(n=12\right.$; Saanen $F_{1}$ : 6, Alpin $\left.F_{1:} 6\right)$ and treatment $\left(n=12\right.$; Saanen $F_{1:}$, Alpin $F_{1:}$ 6). The control group was fed with $7 \mathrm{mg} / \mathrm{kg}$ DM copper-sulfate and $20 \mathrm{mg} / \mathrm{kg}$ DM zinc-sulphate (14). The treatment group was given $5.25 \mathrm{mg} / \mathrm{kg} \mathrm{DM}$ copper-chelate $(\mathrm{Cu}-2-$ hydroxy-4-methylthiobutyrate) and $15 \mathrm{mg} / \mathrm{kg}$ DM zincchelate (Zn-2-hydroxy-4-methylthiobutyrate) in an organic form, which is $25 \%$ less than recommended mineral level. The ration was organized to provide the nutrient requirements of the goat (14).

Trial was conducted with the approval of local Ethics Committee (approval no: 124-HEK/2009/65). Experiment is lasted in 60 days after 15 days of adaptation period. . The kids were fed as a group. The concentrate and vitamin-mineral premix were weighed daily for each group and given as a single meal. Wheat straw was given in two parts after the concentrate was consumed. A total of $832 \mathrm{~g}$ of ration weighed and given to kid and ad libitum water was given during the treatment.

Blood samples were collected from vena jugularis in the beginning and end of the study. Blood samples were collected in the morning before feeding. $\mathrm{Cu}$ and $\mathrm{Zn}$ levels were determined spectrophotometer (Shimadzu Corp. UV-1601, Australia) using a commercial kit (Randox, Cu:Cu2340 and Zn:Zn2341, Ardmore, United Kingdom).

Concentrate and wheat straw samples were taken at the beginning of the study and hair samples (close to the skin) were taken at the beginning and end of the study from the kid's shoulder, rib and hind. The faeces sample was taken from the rectum with the aid of a finger at the end of the study in the morning after feeding. The copper and zinc levels of the samples were determined by using ICP (Inductively Coupled Plasma Spectro - Optima 2100 DV ICP / OES, PERKIN ELMER).

The statistical analyses were performed using the SPSS $^{\odot} 15.0$ package program. The differences of the group means for the examined parameters in the group were determined using Student's t-test (25).

\section{Results}

Ration composition given to kids is shown in Table 1. The $\mathrm{Cu}$ and $\mathrm{Zn}$ levels in wheat straw and consantrate are presented in Table 2. Serum copper and zinc levels at the beginning and end of the study are given in Table 3. The $\mathrm{Cu}$ and zinc levels determined in the hair and feaces are given in Table 4 and Table 5 respectively.

Table 1. The ration composition given to kids.

Tablo 1. Araştırmada oğlaklara verilen rasyonun bileşimi.

\begin{tabular}{lcc}
\hline Ration Composition (\%) & $\begin{array}{c}\text { Control } \\
\text { Group } \\
\text { (Inorganic } \\
\text { mineral) }\end{array}$ & $\begin{array}{c}\text { Treatment } \\
\text { Group } \\
\text { (Organic } \\
\text { mineral) }\end{array}$ \\
\hline Wheat straw (\%)DM & 48.08 & 48.08 \\
Consantrate (\%)DM & 48.08 & 48.08 \\
Vitamin-mineral mix (\%) & 3.84 & 3.84 \\
ME, kcal/kg DM (analysis) & 2854 & 2854 \\
CP, g/kg DM (analysis) & 164 & 164 \\
Cu, ppm*(from premix) & 7 & 5.25 \\
Zn, ppm*(from premix) & 20 & 15 \\
Cu, ppm (from wheat straw) & 3.48 & 3.48 \\
Zn, ppm (from wheat straw) & 3.92 & 3.92 \\
Cu, ppm (from concentrate) & 3.06 & 3.06 \\
Zn, ppm (from concentrate) & 8.12 & 8.12 \\
\hline
\end{tabular}

* In $1.0 \mathrm{~kg}$ of the vitamin-mineral mix, there is $16000000 \mathrm{IU}$ vitamin A, $3200000 \mathrm{IU}$ vitamin $\mathrm{D}_{3}, 32000 \mathrm{mg}$ vitamin $\mathrm{E}, 80$ g salt, $320 \mathrm{~g}$ DCP, $640 \mathrm{mg}$ manganese, $1120 \mathrm{mg}$ iron, $16 \mathrm{mg}$ iodine, $3.20 \mathrm{mg}$ cobalt, $6.40 \mathrm{mg}$ selenium, $16 \mathrm{mg}$ molybdenum, and $256 \mathrm{mg}$ magnesium. Also, there is $640 \mathrm{mg}$ zinc and $224 \mathrm{mg}$ copper in the inorganic mix, and $480 \mathrm{mg}$ zinc and $168 \mathrm{mg}$ copper in the organic mix.

DM; dry matter, ME; metabolic energy, CP; crude protein

Table 2. $\mathrm{Cu}$ and $\mathrm{Zn}$ levels in wheat straw and concentrate (DM, ppm).

Tablo 2. Buğday samanı ve yoğun yemdeki $\mathrm{Cu}$ ve $\mathrm{Zn}$ değerleri (KM, ppm)

\begin{tabular}{lc}
\hline & $\begin{array}{c}\text { For Control and treatment } \\
\text { groups }\end{array}$ \\
\hline Wheat straw $\mathrm{Cu}(\mathrm{DM}, \mathrm{ppm})$ & 7.25 \\
Wheat straw $\mathrm{Zn}(\mathrm{DM}, \mathrm{ppm})$ & 8.16 \\
Consantrate $\mathrm{Cu}(\mathrm{DM}, \mathrm{ppm})$ & 6.38 \\
Consantrate $\mathrm{Zn}(\mathrm{DM}, \mathrm{ppm})$ & 16.9 \\
\hline
\end{tabular}

DM; dry matter, KM; kuru madde

Table 3. Serum copper and zinc levels at the beginning and end of the study $(\mu \mathrm{g} / \mathrm{dl})$.

Tablo 3. Deneme başı ve deneme sonu serum ortalama $\mathrm{Cu}$ ve Zn değerleri $(\mu \mathrm{g} / \mathrm{dl})$.

\begin{tabular}{lccc}
\hline & $\begin{array}{c}\text { Control } \\
\text { Group } \\
(\mathrm{n}=12)\end{array}$ & $\begin{array}{c}\text { Treatment } \\
\text { Group } \\
\bar{X}_{ \pm S_{\bar{x}}}\end{array}$ & $\mathrm{~F}$ \\
$(\mathrm{n}=12) \bar{X}_{ \pm S_{\bar{x}}}$ & \\
\hline Initial serum Cu level & $85.739 \pm 4.878$ & $77.338 \pm 4.541$ & $0.2208 \mathrm{NS}$ \\
Final serum Cu level & $123.093 \pm 5.309$ & $127.780 \pm 5.848$ & $0.5590 \mathrm{NS}$ \\
Initial serum Zn level & $105.339 \pm 3.275$ & $107.438 \pm 3.585$ & $0.6697 \mathrm{NS}$ \\
Final serum Zn level & $116.262 \pm 3.719$ & $122.474 \pm 4.631$ & $0.3075 \mathrm{NS}$ \\
\hline
\end{tabular}

NS: non-signficant 
Table 4. Hair copper and zinc values at the beginning and end of the study (ppm).

Tablo 4. Deneme başı ve deneme sonu kıl ortalama $\mathrm{Cu}$ ve $\mathrm{Zn}$ değerleri (ppm).

\begin{tabular}{lccc}
\hline & $\begin{array}{c}\text { Control Group } \\
(\mathrm{n}=12) \bar{X} \pm S_{\bar{x}}\end{array}$ & $\begin{array}{c}\text { Treatment Group } \\
(\mathrm{n}=12) \bar{X} \pm S_{\bar{x}}\end{array}$ & F \\
\hline Initial hair Cu level & $13.755 \pm 0.356$ & $13.048 \pm 0.423$ & 0.2154 NS \\
Final hair Cu level & $16.509 \pm 0.745$ & $17.920 \pm 0.636$ & 0.1642 NS \\
Initial hair Zn level & $145.000 \pm 7.237$ & $143.700 \pm 8.561$ & 0.9088 NS \\
Final hair Zn level & $156.191 \pm 11.652$ & $153.466 \pm 7.809$ & 0.8480 NS \\
\hline
\end{tabular}

NS: non-signficant

Table 5. The mean $\mathrm{Cu}$ and $\mathrm{Zn}$ values in the kids faeces (ppm).

Tablo 5. Dışkıda bulunan ortalama $\mathrm{Cu}$ ve $\mathrm{Zn}$ değerleri (ppm).

\begin{tabular}{lccc}
\hline & $\begin{array}{c}\text { Control Group } \\
(\mathrm{n}=12) \bar{X} \pm S_{\bar{x}}\end{array}$ & $\begin{array}{c}\text { Treatment Group } \\
(\mathrm{n}=12) \bar{X} \pm S_{\bar{x}}\end{array}$ & $\mathrm{~F}$ \\
\hline Final feaces Cu level & $34.089 \pm 2.078$ & $24.246 \pm 1.619$ & $0.001^{* *}$ \\
Final feaces $\mathrm{Zn}$ level & $90.127 \pm 4.654$ & $51.640 \pm 3.669$ & $0.001^{* *}$ \\
\hline$* *: \mathrm{P}<0.001$ &
\end{tabular}

**: $\mathrm{P}<0.001$

\section{Discussion and Conclusion}

The serum $\mathrm{Cu}$ levels determined at the beginning and end of the study did not differ significantly. However, while the mean serum $\mathrm{Cu}$ value was numerically higher in the control group at the beginning of the study, the treatment group's mean serum copper value was higher at the end of the study. Similarly, the difference between the mean serum zinc values was not statistically significant; it was numerically higher in the treatment group at the end of the study (Table 3). Rojas et al. (18) showed that the serum zinc value significantly $(\mathrm{P}<0.05)$ increases in lambs given organic minerals Ryan et al. (20) demonstrated that the plasma copper value $(\mathrm{P}<0.001)$ and plasma zinc value $(\mathrm{P}<0.05)$ in sheep given lower levels of organic minerals were significantly high. Similar findings were reported by Eckert et al. (7) for copper proteinate and Eren et al. (8) for copper-chelate and zinc-chelate in sheep and by Mondal et al. (13) for the organic forms of copper, zinc and manganese that were given at a $50 \%$ lower level. Additionally, Rojas et al. (19) in heifers, Salama et al. (21) in goats, and Spears and Kegley (24) found similar organic and inorganic minerals levels in serum samples collected from calves.

Although the mean hair $\mathrm{Cu}$ value seemed to be numerically higher in the control group at the beginning of the study, the treatment group had numerically higher $\mathrm{Cu}$ values at the end of the study (Table 4).

There was no difference statistically significant in the mean hair $\mathrm{Zn}$ value between the control and treatment groups. However, at the beginning and end of the study, the mean hair zinc values were numerically higher in the control group (Table 4). Ryan et al. (20) showed that adding zinc to the diet of Texel sheep increases the wool zinc level significantly $(\mathrm{P}<0.05)$; however, giving the zinc in forms of a sulphate or an amino acid chelate did not give a significant difference. Wright and Spears (29) determined that the hair of the calves given zinc proteinate accumulate a higher level of zinc compared to calves given zinc sulphate but that the difference was not statistically significant. It has previously been determined that adding zinc that has been chelated with amino acids to the diet enables hair to grow longer in dogs and that the zinc level is higher in comparison to zinc oxide (12). Kuhlman and Rompala (9) compared that the hair of the dogs given copper, zinc and manganese proteinate with dogs given copper, zinc and manganese sulphate but that the difference was not statistically significant. Similar findings were reported by Eren et al. (8) for copperchelate and zinc-chelate in sheep.

In this study, the mean $\mathrm{Cu}$ and mean $\mathrm{Zn}$ values found in the faeces of the treatment group were significantly lower $(\mathrm{P}<0.001)$ compared to the control group (Table 5). Similar results have been demonstrated in other studies. Research by Nocek et al. (15) in cows, by Wagner et al. (27) in calves and by Mondal et al. (13) in male calves suggest that absorption and bioavailability of organic trace minerals are higher. Thus, when added to the animal rations in lower levels, there is less excretion via faeces and thereby less pollution. Similar results have been found trial conducted with pigs $(1,4,5,6,10)$ and steer (28).

According to the examined parameters, although $25 \%$ less organic copper and organic zinc was added to the kids diet, similar levels were determined for some parameters compared to inorganic copper and zinc, and organic minerals were found at lower levels in the faeces.

\section{References}

1. Armstrong TA, Cook DR, Ward MM, Williams CM, Spears JW (2004): Effect of dietary copper source (cupric 
citrate and cupric sulfate) and concentration on growth performance and fecal copper excretion in weanling pigs. J Anim Sci, 82, 1234-1240.

2. Bao YM, Choct M, Iji PA, Bruerton K (2007): Effect of organically complexed copper, iron, manganese and zinc on broiler performance, mineral excretion and accumulation in tissues. J Appl Poultry Res, 16, 448-455.

3. Boland MP (2003): Trace minerals in production and reproduction in dairy cows. Adv Dairy Tech, 15, 319.

4. Carlson MS, Boren CA, Wu C, Huntington CE, Bollinger DW, Veum TL (2004): Evaluation of various inclusion rates of organic zinc either as polysaccharide or proteinate complex on the growth performance, plasma and excretion of nursery pigs. J Anim Sci, 82, 1359-1366.

5. Case CL, Carlson MS (2002): Effect of feeding organic and inorganic sources of additional zinc on growth performance and zinc balance in nursery pigs. J Anim Sci, 80, 1917-1924.

6. Coffey RD, Cromwell GL, Monegue HJ (1994): Efficacy of a copper-lysine complex as a growth promotant for weanling pigs. J Anim Sci, 72, 2880-2886.

7. Eckert GE, Grene LW, Carstens GE, Ramsey WSJ (1999): Copper status of ewes fed increasing amounts of copper from copper sulfate or copper proteinate, J Anim Sci, 77, 244-249.

8. Eren V, Atay O, Gökdal Ö (2011): Organik bakır ve çinko'nun toklularda canlı ağırlık, serum ve yapă̆ıdaki düzeyleri üzerine etkisi, Kafkas Üniv Vet Fak Derg, 17, 95-99.

9. Kuhlman G, Rompala RE (1998): The influence of dietary sources of zinc, copper and manganese on canine reproducti ve performance and hair mineral content. J Nutr, 128, 2603-2605.

10. Lee SH, Choi SC, Chae BJ, Acda SP, Han YK (2001): Effect of feeding different chelated copper and zinc sources on growth performance and fecal excretions of weanling pigs. Asian Australas J Anim Sci, 14, 1616-1620.

11. Leeson S (2003): A new look at trace minerals nutrition of poultry: Can we reduce environmental burden of poultry manure? In: Lyons TP, Jacques KA, Nutritional Biotechnology in the Feed and Food Industries, Proceedings of the $19^{\text {th }}$ Annual Symposium. Nottingham University Press. Nottingham, United Kingdom. p: 125131.

12. Lowe JA, Wiseman J, Cole DJA (1994): Zinc source infl uences zinc retention in hair and hair growth in the dog. $\mathrm{J}$ Nutr, 124, 2575-2576.

13. Mondal S, Paul SK, Bairagi B, Pakhira MC, Biswas $\mathbf{P}$ (2008): Comparative studies of reducing level of organic with inorganic trace minerals supplementation on the performance, nutrient digesti bility and mineral balance in cross-bred male calves. Livestock Research for Rural Develelopment, 2008. Arti cle \#112. Retrieved October 25, 2008.

[htt p://www.cipav.org.co/lrrd//rrd20/7/mond20112.htm].

14. National Research Council (1985): Nutrient Requirements of Sheep, $6^{\text {th }}$ revised edition, National Academiy of Sciences, Washington, DC.
15. Nocek JE, Socha MT, Tomlinson DJ (2006): The effect of trace mineral fortification level and source on performance of dairy cattle, J Dairy Sci, 89, 2679-2693.

16. Nockels CF, Debonis J, Torrent J (1993): Stress induction affects $\mathrm{Cu}$ and $\mathrm{Zn}$ balance in calves fed organic and inorganic $\mathrm{Cu}$ and $\mathrm{Zn}$ sources. J Anim Sci, 71, 25392545.

17. Nollet L, Huyghebaert G, Spring P (2008): Effect of different levels of dietary organic (Bioplex) trace minerals on live performance of broiler chickens by growth phases. J Appl Poultry Res, 17, 109-115.

18. Rojas LX, McDowell LR, Cousins RJ, Martin FG, Wilkinson NS, Johnson AB, Velasquez JB (1995): Relative bioavailability of two organic and two inorganic zinc sources fed to sheep, J Anim Sci, 73, 1202-1207.

19. Rojas LX, McDowell LR, Martin FG, Wilkinson NS, Johnson AB, Nijeru CA (1996): Relative bioavailability of zinc methionin and two inorganic zinc sources fed to cattle. J Trace Elem Med Biol, 10, 205-209.

20. Ryan PJ, Kearns P, Quinn T (2002): Bioavailability of dietary copper and zinc in adult Texel sheep: $A$ comperative study of the effects of sulphate and bioplex supplementation. Irish Vet J, 55, 221-224.

21. Salama Ahmed AK, Caja G, Albanell E, Such X, Casals R, Plaixtas J (2003): Effects of dietary supplements of zinc-methionine on milk production, udder health and zinc metabolism in dairy goats. J Dairy Res, 70, 9-17.

22. Spears JW (1996): Organic trace minerals in ruminant nutrition. Anim Feed Sci Tech, 58, 151-163.

23. Spears JW (2003): Trace mineral bioavailability in ruminants. J Nutr, 133, 1506-1509.

24. Spears JW, Kegley EB (2002): Effect of zinc source (zinc oxide vs zinc proteinate) and level on performance, carcass characteristi cs, and immune response of growing and fi nishing steers. J Anim Sci, 80, 2747-2752.

25. Sümbüloğlu K, Sümbüloğlu V (1995): Biyoistatistik, Özdemir Yayıncılık, Ankara.

26. Underwood EJ, Sutt le NF (1999): The Mineral Nutrition of Livestock, 3rd ed. 294-482, CABI Publishing, UK.

27. Wagner JJ, Lacey JL, Engle TL (2008): The effect of organic trace minerals on feedyard performance and carcass merit in crossbred yearling steers, Prof Anim Sci, 24, 420-429.

28. Ward TL, Asche GL, Louis GF, Pollmann DS (1996): Zinc-methionine improves growth performance of starter pigs. J Anim Sci, 74, 182 (Abstr.).

29. Wright CL, Spears JW (2001): Effects of zinc source and dietary level on zinc metabolism in Holstein bull calves. $\mathrm{J}$ Anim Sci, 79, 86 (Abstr.).

Geliş tarihi: 09.04.2012 / Kabul tarihi: 06.11.2012

Address for correspondence:

Dr.Vadullah Eren

Adnan Menderes University, Çine Vocational School,

09500, Çine-Aydin, Turkey

e-mail:erenvadullah@yahoo.com 